\title{
Within the Scope of Labor Relations: Relationships of Role Conflict and Ambiguity, Well-Being at Work, Emotional Exhaustion, Co-Worker and Supervisor Support, Reported Job Competence Variables
}

\author{
Şebnem ASLAN ${ }^{1} \odot$, Seda UYAR $^{2} \odot$
}

\begin{abstract}
In this study, it was aimed to investigate the relationships between role conflict, role ambiguity, well-being at work, emotional exhaustion, co-worker support, supervisor support and reported job competence variables in the organizational literature.

The scales used in the study include supervisor support and co-workersupport scale of Paulin, Ferguson and Bergeron (2006), the Reported Job Competence Scale of Warr (1990), the emotional exhaustion scaletaken fromLewin and Sager (2009) whose main source is Singh et al. (1994)'s study, the role conflict scaletaken fromLewin and Sager (2009)whose main source is Rizzo et al. (1970)'s study, role ambiguity scaletaken fromLewin and Sager (2009)whose main source is Rizzo et al. (1970)'s study, and well-being at work scale taken from the study of Daniels (2000).

The study was carried out with randomly selected 400 healthcare professionals from 6 hospitals in 4 cities of Central Anatolia and Eastern Anatoliain 2018. Participants were reached by using the "random sampling" and critical case sampling methods in proportion to the size of the hospital with the " proportional cluster sampling " method.

As a result of the study, a positive relationship was found between co-worker support and supervisor support. Reported job competence showed a negative relationship with role ambiguity and role conflict, and a positive relationship with supervisor support and co-worker support.Well-being at work (positive effect) showed a positive relationship with supervisor support and co-worker support, a negative relationship with well-being at work (negative effect), and a negative relationship with emotional exhaustion.

Keywords: SupervisorSupport, Co-workersupport, ReportedJobCompetence, EmotionalExhaustion, Role Conflict,Role Ambiguity, Well-Being at Work
\end{abstract}

\section{INTRODUCTION}

The multidisciplinary feature of the services provided in health institutions causes them to have complex structures (Koeck, 1998; Thompson, Buchbinder \& Shanks, 2012, p. 2; Rubino, 2012, p. 17; Buchbinder \& Buchbinder, 2012, p. 211-212). This leads employees to experience role conflict and role ambiguity (Esatoğlu et al., 2004, p. 134). The ambiguity or conflict experienced by the employee is evaluated as factors that reduce job performance, satisfaction and organizational effectiveness (Rizzo et al., 1970). Emotional exhaustion (Maslach and Leiter, 1997; Çam, 1992), which is regarded as a problem affected by variables related to the profession and work environment rather than individual variables, is mostly seen in sectors with intense face-to-face relations (Sumeli, 2011).

Another variable that is thought to affect organizational outcomes is co-worker support and supervisor support (BabinandBoles, 1996). When considered in terms of employees, the supportive organizational culture in the institution where they work is important (Kale, 2015).

Whether there is a relationsamong the variables of role conflict, role ambiguity, well-being at work, emotional exhaustion, co-worker support, supervisor

${ }^{1}$ Prof.Dr., Selcuk University, Health care Management, sebnemaslan27@hotmail.com

${ }^{2}$ Dr., Selcuk University, Health care Management, seda_inan@outlook.com 
support and reported job competence, and if so, the direction, scope, details and conditions of this relationshipseems worth putting forward as a basic research question.In this respect, it is thought that the study will contribute to the literature. Therefore, firstly, a brief literature information about the concepts is given, the relationship between these concepts is examined and the results of the research conducted in health institutions are discussed.

\section{LITERATURE REVIEW}

\subsection{Role Conflict and Role Ambiguity}

Role is defined as the behavioral patterns required by a position (Riggio, 2014). In other words, it includes the behaviors expected from the individual regarding the organizational and social status (Işık, 2014). Role conflict is expressed as the situation that occurs when a person takes on more than one role at the same time and these roles conflict (Trayambak et al., 2012, p. 47). Role conflict is also defined as "involving incompatibility between employees, resources, rules or policies and other people." Katz and Khan (1978) define role conflict as "the situation that occurs when a person is confronted with the expectation of two or more roles simultaneously".

Role ambiguity is defined as the uncertainty experienced by a person with a role about what $\mathrm{s} /$ he should do while performing that role (Palomino \& Frezatti, 2016, p. 167). According to Peterson et al. (1995, p. 430), it is defined as the uncertainty that arises about what activities will be donein order to fulfill the responsibilities of a role. With a similar expression, it is defined as the situation in which individuals do not know what to do about the role whose responsibilities they assume. (Katz and Kahn, 1977, p. 215).The ambiguity experienced by the individual can negatively affect the performance of the employee as well as the effectiveness of the organization (Rizzo et al., 1970; Katz and Khan, 1978). In particular, not knowing or not understanding the expected behaviors for the job causes the person not to know whether his/her abilities are sufficient to fulfill the role. (Madera et al., 2013, p. 29; Srikanth and Jomon, 2013, p. 107).

The basic definitions on role ambiguity seem to be based on the concepts of 'ambiguity' and 'lack of knowledge' (Pearce 1981), while role conflict involves the conflict of two or more role pressures with each other (Kahn et al., 1964).

\subsection{Reported job competence}

Reported job competence is defined as having the knowledge, ability and experience required by the working conditions (Kane, 1992, p. 165). Reported job competence includes the will to work as well as the physical and mental health status (Ilmarinen et al., 1997; Ilmarinen and Rantaten, 1999).

The differences in working conditions and requirements during the fullfilment of professions also lead to differences in the professional competencies to be possessed (Topliceanu et al., 2014, p. 1034). According to some job descriptions, skills such as critical thinking, teamwork, and communication, which are accepted as high-level talents, are considered professional competence, while only having physical strength or knowing technical knowledge are also regarded as professional competence (Litcfield et al., 2002, p.1455). In short, reported job competence can be expressed as the ability to cope with working life (Chiu et al., 2007).

Since reported job competence is related to the person performing the roles required by the job, the qualifications possessed reduce role ambiguity and role conflict (Minnick, 2010). According to the research conducted on healthcare professionals, it is seen that the reason for the role ambiguity in working life is the lack of qualifications to be possessed (Yörükoğlu, 2008). In addition, professional experience is considered to be related to role conflict (Akbulut, 2013). Therefore, the following hypotheses have been proposed:

H1a. Role conflict is negatively related to reported job competence.

H1b. Role ambiguity is negatively related to reported job competence.

\subsection{Co-worker support and Supervisor support}

The support shown by the primary supervisor of the employee is defined as supervisor support (Yoon and Lim, 1999). Supporting, encouraging and showing attention to the needs of the employee is also within the scope of supervisor support. (Babin and Boles, 1996, p. 60). Supervisor support (Bhanthumnavin, 2003, p. 79), which means a positive business relationship between the supervisor and the employee, includes all behaviors that have positive effects on the satisfaction and performance of the employee (DeConinck and Johnson, 2009 , p. 340). Supervisor support is also expressed as a positive business relationship between the supervisor and the employee (Bhanthumnavin, 2003). It includes 
the supervisor's contributions to the employee, such as evaluating and guiding the employeeand assessing his/her performance (Eisenberger et al., 2002, p. 567). According to Powell (2011),supervisor's awareness of human resources as the most valuable resource for the organization and making employees feel this and paying attention to the quality of work life are also included in the concept of supervisor support.

Co-worker support includes interaction with other employees at the same organization level, helping behavior and support intentions (Mossholder et al., 2005, p. 609; Harris et al., 2007, p.150). According to Yoon and Lim (1999), co-worker support is defined as the support the employee receives from people in similar positions and with whom he / she works. Social support theory (Mossholderve et al., 2005, p. 609) defined as the intention to help others in the workplace constitutes the main theme of co-worker support (Harris et al., 2007 , p. 150). According to the social support theory, an employee's acceptance and support, especially from his/her co-worker, is seen as a requirement (Rhoades and Eisenberger, 2002). Employee's perception of being supported positively reflects on many job-related behaviors (Mossholder et al., 2005, p. 609).

An organizational culture that cares about the support of both co-workers and supervisors can improve employees' positive attitudes towards the job and increase their productivity (Babin and Boles, 1996, p. 58). Especially a supportive managerial attitude is seen as a need for employees to reach professional competence (Bhanthumnavin, 2003). It is predicted that the supervisor support will contribute to the attitudes and behaviors of the employees and will improve their perceptions before the organization. (DeConinck and Johnson, 2009). Thus, the following hypotheses have been proposed:

H2a. Supervisor support is positively related to co-worker support.

H2b. Reported job competence is positively related to supervisor support.

H2c.Reported jobcompetence is positively related to co-worker support.

\subsection{Emotional Exhaustion}

The concept of exhaustion, which is described as an occupational hazard, first entered the literature in 1974 and it is defined as" the loss of power and energy due to failure, fatigue and overload or the state of exhaustion in the internal resources of the individual as a result of unfulfilled requests" (Freudenberger, 1974, p. 159). The burnout model is defined as a syndrome with three components: emotional exhaustion, depersonalization, and decrease in personal success (Maslach, Schaufeli, \& Leiter, 2001). High level of emotional exhaustion and depersonalization and low level of personal success are indicative of high burnout (Cordes and Dougherty, 1993, p. 624).

Emotional exhaustion, which is expressed as the beginning and the clearest symptom of burnout, emerges when the individual consumes his / her emotional resources (Cordes and Dougherty, 1993, p. 624). Emotional exhaustion, which represents the stress dimension of burnout, is defined as the state of running out of energy due to exposure to psychological and emotional demands (Jackson, 1986). It is also expressed as the stress caused by the demands and changes required by the job (Sürgevil, 2006). Emotional exhaustion, which is also seen as the internal dimension of burnout, can cause symptoms such as fatigue and lack of energy (Leiter and Maslach, 1988, p. 297). Chronic fatigue occurs with the continuation of emotional exhaustion, which can lead to physical exhaustion (Skaalvik and Skaalvik, 2009, p.518). Emotional exhaustion, which is also defined as an occupational disorder (Barutçu and Serinkan, 2008, p.545), is associated with many negative outcomes both personally and organizationally (Meydan et al., 2011).

When the factors affecting burnout are examined, it is seen that the employee's co-workers in the workplace reduce burnout (Torun, 1997, p. 44-45,49), and the support from the co-workers provides a more emotionally stable stanceas well as job satisfaction. (Leiter and Maslach, 1988). Thus, the following hypothesis has been established:

H3. Co-worker support is negatively related to emotional exhaustion.

\subsection{Well-Being at Work}

Well-being at work is defined as the sum of positive and negative feelings experienced by the individual towards the job (Bakker and Oerlemans, 2011, p.178179). According to Bakker and Oerlemans (2011), well-being at work means that the employee feels positive emotions such as satisfaction, pleasure and happiness more than negative emotions such as grief and anger. Similarly, Bradburn (1969) defines well-being as positive emotions being superior to negative. War (1990), on the other hand, describes the well-being with elements such as the ability of participating in the 
social group, having self-confidence and always being in a positive psychological state.

Especiallythe factors affecting well-being are emphasized in the studies (Christopher, 1999). Ryff (1989) states that the individual's relationships with other people around him/her have a dominant role in his/her psychological well-being. In particular, the degree of relationship between the employee and the supervisor affects the well-being of the employee in the workplace (Agenda, 2007). In the study of Babin and Boles (1996), it is seen that the support of co-workers and supervisors contributes to positive outcomes in the workplace. It is stated that there is a relationship between the practices of supervisors and the organizational wellbeing levels of employees (What Works Center for Wellbeing, 2017, p.16), and environmental characteristics have a great effect on the well-being of individuals (Warr, 2007, p. 17). Another factor affecting well-being is emotional exhaustion that causes negative feelings in employees (Torun, 1997, p. 49; Bakker and Oerlemans, 2011, p. 179-180; Schaufeli, 2011, p. 22). Emotional exhaustion thatthe employee has to experience is fed by negative situations in the work environment and eliminated by conditions that ensure being good at work (Maslach, 1999, p. 50-53; Freisen and Sarros, 1989, p. 185; Cordes and Dougherty, 1993, p. 633; Maslach et al., 2001, p. 413-415; Sweeney and Summers, 2002, p. 223; Budak and Sürgevil, 2005, p. 97). Thus, the following hypotheses have been established:

H4a. Well-being at work (positive impact) is positively related tosupervisor support.

H4b. Well-being at work (positive impact) is positively related to co-worker support.

H4c. Work well-being (positive impact) is negatively related to emotional exhaustion.

H4d. Well-being at work (negative impact) is negatively related to supervisor support.

H4e. Well-being at work (negative impact) is negatively related to co-worker support.

\section{METHOD}

\subsection{Research Model}

In this study, role conflict, role ambiguity, well-being at work, emotional exhaustion, co-worker support, supervisor support and reported job competence relationships were investigated. The data were evaluated with SPSS 10.0. Confirmatory factor analysis (CFA) was applied with the LISREL VIII program to measure its validity. In addition, descriptive statistics and path analysis were performed.

\subsection{Participants}

The study was carried out with randomly selected 400 healthcare professionals from 6 hospitals in 4 cities from Central Anatolia and Eastern Anatolia. Participants were reached by using the "random sampling" and critical case sampling methods in proportion to the size of the hospital with the "proportional cluster sampling" method. More clearly, in Turkey which was specified as population for the study, 1 region (Central Anatolia Region) from 6 regions (Aegean, Mediterranean, Southeast, Black Sea, Central Anatolia, Marmara) reflecting the average situation was taken as the sample with the random sampling method and the Eastern Anatolia Region reflecting a situation where living conditions are more difficult was taken as the sample with critical case sampling method. "Random sampling method means that each situation and each subset have an equal chance of being selected" (Montello and Sutton, 2006, p. 155; Altındiş and Ergin, 2018, p.93). The indicator in determining the critical situation is: "If this situation is happening there, it can happen everywhere, or if this situation is not happening there, it will not happen anywhere" are the statements indicating the existence or absence of any judgment (Patton, 2014, p. 236; Altındiş and Ergin, 2018, p. .93). After the regions to be included in the study, two provinces in those regions and three hospitals from the selected provinces were included in the sample with random sampling. The proportional cluster sampling method was used in the selection of participants from 6 hospitals within the scope of the study. Proportional cluster sampling means that after the population is divided into sub-phases according to the variables that are predicted to differ, each sub-phase has an equality to reflect its chances of entering the sampling within the whole (Karasar, 2004, p. 115). Therefore, our sample was proportioned to the hospital sizes and the sample was created to reflect the equality.

The majority of the participants in the study were single (51.8\%), had high school degree (33.8\%) and associate degree $(39.5 \%)$, were administrative staff $(63.5 \%)$, nurse $(30.5 \%)$ and female $(56.5 \%)$, the majority of them consisted of employees in the 18-27age group $(52.8 \%)$ and in the $28-37$ age group (38.5\%).

\subsection{Scales}

In the study, co-worker support, supervisor support and reported job competence scales were used in the 
relationship between role conflict and role ambiguity, well-being at work and emotional exhaustion.

Supervisor Support and Co-workerSupport Scale:It was taken from the study of Paulin, Ferguson and Bergeron (2006). The scale includes 5 questions about supervisor supportand 4 questions about co-worker support. The scale questions were translated from English to Turkish by translation-back translation method by 8 academic staff from the field, and it was rated as "Not effective at all $=1$ " and "Very effective = 7" with 7-point Likert. In the study of Paulin, Ferguson and Bergeron (2006), the Cronbach Alpha coefficient of the two sub-dimensions of the scale was found to be at a high level of .92-.93, respectively. In this study, the construct validity of the scale was examined with the Confirmatory Factor Analysis, and its reliability with the Cronbach Alpha coefficient.

Reported job competence Scale: The source of the scale is the study of Warr (1990) with 6 questions. The scale questions were translated from English to Turkish by translation-back translation method by 8 academic staff. In Warr's (1990) study, the Cronbach Alpha coefficient of the scale was found between .68 and .62. The scale was rated with a 5-point Likert (1 $=$ Strongly Disagree, $5=$ Strongly Agree). In the scale, questions 2, 4 and 6 were reverse coded. In this study, the construct validity of the scale was examined with the Confirmatory Factor Analysis and its reliability with the Cronbach Alpha coefficient.

Emotional Exhaustion Scale: The main source of the scale taken from Lewin and Sager (2009)'s study is the study of Singh et al. (1994). The scale questions were translated from English to Turkish by translation-back translation method by 8 academic staff. In the study of Lewin and Sager (1990), construct reliability with the $C R$ coefficient of the scale was found as high as .92. The scale was rated with a 5-point Likert ( $1=$ Strongly Disagree, 5 = Strongly Agree). In this study, the construct validity of the scale was examined with the Confirmatory Factor Analysis, and its reliability with the Cronbach Alpha coefficient.

Role Conflict Scale: The main source of the scale taken from Lewin and Sager (2009)'s study is Rizzo et al. (1970) 's study. The scale, which consists of six questions, was rated with a 5-point Likert ( 1 = Strongly disagree, 7 = Strongly Agree). In the study of Lewin and Sager (1990), the construct reliability with the CR coefficient of the scale was found to be 0.89 . In this study, the construct validity of the scale was examined with the Confirmatory Factor Analysis, and its reliability with the Cronbach Alpha coefficient.

Role Ambiguity Scale: The main source of the scale taken from Lewin and Sager (2009) is Rizzo et al. (1970) 's study. The reverse-coded scale consisting of five questions was rated with a 5-point Likert ( 1 = Strongly disagree, 7 = Strongly Agree). In the study of Lewin and Sager (1990), the construct reliability with the CR coefficient of the scale was found to be .87. In this study, the construct validity of the scale was examined with the Confirmatory Factor Analysis, and its reliability with the Cronbach Alpha coefficient.

Well-Being at Work Scale: The scale taken from the Daniels (2000)'s study consists of 30 questions and two sub-dimensions, negative effect and positive effect. Negative effect sub-dimension includes "A-C anxiety-comfort", "D-P depression-pleasure,, "A-P angry-placid", "B-E bored-enthusiastic", "T-V tiredness-vigor"sub-dimensionswhich consist of three questions each. Positive effect sub-dimension consists of "A-C anxiety-comfort", "D-P depression-pleasure", "A-P angry-placid", "B-E bored-enthusiastic" and "T-V tiredness-vigor" sub-dimensions. The scale is rated with 6 Likert $(1=$ Never, 7 $=$ All the time). The Cronbach Alpha coefficient in the study of Daniels (2000) was found between .79 and .86. In this study, the construct validity of the scale was examined with the Confirmatory Factor Analysis, and its reliability with the Cronbach Alpha coefficient.

\subsection{Results}

The construct validity of the scales was examined with Confirmatory Factor Analysis and the construct reliability with the Cronbach's Alpha coefficient (internal consistency of measures). In the confirmatory factor analysis, the t value should also be significant. In the interpretation of the item-total test correlation, items with .30 and higher are considered to distinguish individuals well in terms of measured characteristics. The relation of each item with the overall scale score(item-total correlation) was examined. Accordingly, the correlation coefficients should not be negative and should be $>0.25$.

As a result of the analyzes, the goodness of fit indices $\mathrm{X} 2$ / df ratio, RMSEA, GFI, NFI, CFI, NNFI, AGFI were investigated. $X 2 / \mathrm{df}<5$ indicates that it is acceptable, while $\mathrm{X} 2$ / $\mathrm{df}<2$ indicates that it is at a good fit. For RMSEA value, $0 \leq$ RMSEA $\leq$.05is considered asgood fitand $.05<$ RMSEA $\leq .08$.as acceptable fit. For GFI value, $.95 \leq \mathrm{GFI} \leq 1.00$ is considered as good fit and. $90 \leq \mathrm{GFI}$ $<95$ as acceptable fit. For NFI value, $.95 \leq \mathrm{NFI} \leq 1.00$ is 
regarded as good fitand $.90 \leq \mathrm{NFI}<.95$ as acceptable fit. For CFI value, $.97 \leq \mathrm{CFI} \leq 1.00$ is considered as good fit and $.95 \leq \mathrm{CFI}<.97$ as acceptable fit. For NNFI value, .97 $\leq \mathrm{NNFI} \leq 1.00$ is considered as good fitand $.95 \leq \mathrm{NNFI}$ $<.97$ as acceptable fit. Finally, for AGFI,.90 $\leq \mathrm{AGFI} \leq 1.00$ is regarded as good fit and. $85 \leq \mathrm{AGFI}<.90$ as acceptable fit (Steiger, 1994; Stevens, 2009).
As seen in Table 1, a good fit was reachedas the goodness of fit indicator in the initial version of the supervisor support and co-worker support scale(Goodness-of-Fit Statistics: $X 2 / d f=92.79 / 26=3.56, N F I=.95$, $N N F I=.95, C F I=.97, A G F I=.91, \mathrm{GFI}=.95, \mathrm{RMSEA}=.08)$. Thus, the initial version of the 9-item scale consisting of two sub-dimensions was found valid and reliable in Turkey (Cronbach: .88, .84, .90).

Table 1: Confirmatory factor analysis result: supervisor support and co-worker support

\begin{tabular}{|c|c|c|c|c|c|}
\hline Dimensions & (CFA) & $t$-value & Mean & Std.Dev. & $\begin{array}{l}\text { Item-Total } \\
\text { Corelation }\end{array}$ \\
\hline Supervisor and co-worker support scale* & \multicolumn{5}{|c|}{ Cronbach Alpha:.90 } \\
\hline Supervisor Support Dimension & \multicolumn{5}{|c|}{ Cronmbach Alpha:. 88} \\
\hline 1 & .83 & 19.63 & 2.54 & 1.116 & $.834 * *$ \\
\hline 2 & .81 & 18.87 & 2.74 & 1.085 & $.812 * *$ \\
\hline 3 & .72 & 15.94 & 2.78 & 1.074 & $.740 * *$ \\
\hline 4 & .76 & 17.29 & 2.52 & 1.030 & $.790 * *$ \\
\hline 5 & .70 & 15.49 & 2.54 & 1.130 & $.734 * *$ \\
\hline Co-worker Support Dimension & \multicolumn{5}{|c|}{ Cronmbach Alpha:. 84} \\
\hline 6 & .80 & 18.47 & 2.97 & 1.106 & $.818 * *$ \\
\hline 7 & .82 & 18.83 & 2.94 & 1.167 & $.808 * *$ \\
\hline 8 & .83 & 19.28 & 3.08 & 1.187 & $.828 * *$ \\
\hline 9 & .60 & 12.56 & 2.68 & 1.292 & $.724^{* *}$ \\
\hline
\end{tabular}

Note: Standardized item loadings reported for CFA. $p<.001$ for all loadings. ${ }^{* *}$ Correlation is significant at the 0.01 level (2-tailed).

* The question with a factor load below .30 and dropped from the scale ** The question that was droppedfor remaining single in the dimension ${ }^{a}$ Question giving a correction index and removed from the scale

* Thequestions corresponding to the study of Paulin, Ferguson and Bergeron (2006).

Table 2: Confirmatory factor analysis result: reported job competence

\begin{tabular}{lccccccc}
\hline Dimensions & (CFA)* & (CFA)* & (CFA) & t-value & Mean & Std.Dev. & $\begin{array}{l}\text { Item-Total } \\
\text { Corelation }\end{array}$ \\
\hline $\begin{array}{l}\text { Reported job competence Scale* } \\
\text { Cronbach Alpha:.63 }\end{array}$ & & & & & & & \\
\hline 1 & .36 & .46 & .46 & 6.42 & 4.16 & .964 & $.633^{* *}$ \\
\hline 2 & $.00^{*}$ & & & & & & \\
\hline 3 & .34 & $.29^{*}$ & & & & & \\
\hline 4 & $.72 *$ & & & & & & \\
\hline 5 & .56 & .69 & .67 & 7.46 & 3.83 & .930 & $.699^{* *}$ \\
\hline 6 & .59 & .45 & .47 & 6.47 & 3.56 & 1.132 & $.714^{* *}$ \\
\hline
\end{tabular}

Note: Standardized item loadings reported for CFA. $p<.001$ for all loadings. ${ }^{* *}$ Correlation is significant at the 0.01 level (2-tailed).

* The question with a factor load below. 30 and dropped from the scale ** The question that was dropped for remaining single in the dimension ${ }^{a}$ Question giving a correction index and removed from the scale

*Thequestions corresponding to Warr (1990)'s study. 
As seen in Table 2, a good fitcould not be reached asthe goodness of fit indicator in the initial version of the reported job competence scale (Goodness-of-Fit Statistics: $2 / d f=47.09 / 9=5.23, N F I=.83, N N F I=.75$, $\mathrm{CFI}=.85, \mathrm{AGFI}=.91, \mathrm{GFI}=.96, \mathrm{RMSEA}=.10)$. The 2nd question with a factor load of less than .30 and the 4th question showing the correction index were dropped from the scale, and the scale was subjected to confirmatory factor analysis again, and a good fit was not reached (Goodness-of-Fit Statistics: $X 2 / d f=1.31 / 2=$ $.65 \mathrm{NFI}=.99, \mathrm{NNFI}=1.00, \mathrm{CFI}=1.00, \mathrm{AGFI}=.99, \mathrm{GFI}=$ $1.00, R M S E A=.00$ ). The 3rd question with a factor load of less than .30 and showing a correction index was dropped from the scale, and the scale was subjected to confirmatory factor analysis again, and a good fit wasreached (Goodness-of-Fit Statistics: $\chi 2 / d f=1.31 / 2$ $=.65, \mathrm{NFI}=.99, \mathrm{NNFI}=1.00, \mathrm{CFI}=1.00, \mathrm{AGFI}=1.00, \mathrm{GFI}$
$=1.00, R M S E A=.00)$. Thus, a new 3-item reported job competence scale that is valid and reliable (Cronbach's Alpha: .63) in Turkeywas obtained.

As seen in Table 3, a good fit could not be reached as the indicator of goodness of fit in the initial version of the emotional exhaustion (Goodness-of-Fit Statistics: X2/df $=29.04 / 9=3.22, \mathrm{NFI}=.93, \mathrm{NNFI}=.91, \mathrm{CFI}=.95, \mathrm{AGFl}=.94$, $\mathrm{GFI}=.98, \mathrm{RMSEA}=.07)$. The 1st question showing the correction index was dropped from the scale and the scale was re-subjected to confirmatory factor analysis and a good fit wasreached $(X 2 / d f=10.94 / 5=2.18, N F I$ $=.96, \mathrm{NNFI}=.95, \mathrm{CFI}=.98, \mathrm{AGFI}=.97, \mathrm{GFI}=.99, \mathrm{RMSEA}=$ .05). Thus, a new five-item emotional exhaustion scale which is valid and reliable (Cronbach's Alpha: .68) in Turkey was obtained.

Table 3: Confirmatory factor analysis result: emotional exhaustion

\begin{tabular}{lcccccc}
\hline Dimensions & (CFA) & (CFA) & $t$-value & Mean & Std.Dev. & Item-Total Corelation \\
\hline $\begin{array}{l}\text { Emotional Exhaustion Scale* } \\
\text { Cronbach Alpha: } \mathbf{6 8}\end{array}$ & & & & & & \\
\hline 1 & $.54^{*}$ & & & & & \\
\hline 2 & .56 & .50 & 8.80 & 2.95 & .980 & $.595^{* *}$ \\
\hline 3 & .58 & .55 & 9.65 & 2.96 & 1.071 & $.607^{* *}$ \\
\hline 4 & .46 & .50 & 8.67 & 2.96 & 1.005 & $.613^{* *}$ \\
\hline 5 & .60 & .65 & 11.43 & 3.05 & .985 & $.635^{* *}$ \\
\hline 6 & .54 & .55 & $\mathbf{9 . 6 8}$ & $\mathbf{3 . 0 2}$ & $\mathbf{1 . 0 1 8}$ & $.620^{* *}$ \\
\hline
\end{tabular}

Note: Standardized item loadings reported for CFA. $p<.001$ for all loadings. ${ }^{* *}$ Correlation is significant at the 0.01 level (2-tailed).

*The question with a factor load below.30 and dropped from the scale *** The question that was dropped $d$ for remaining single in the dimension

${ }^{a} Q u e s t i o n$ giving a correction index and removed from the scale

* The questions that correspond to the study of Lewin and Sager (2009).

Goodness-of-Fit Statistics: $X 2 / d f=29.04 / 9=3.22, N F I=.93, N N F I=.91, C F I=.95, A G F I=.94, G F I=.98, R M S E A=.07$

Goodness-of-Fit Statistics: $X 2 / d f=10.94 / 5=2.18, \mathrm{NFI}=.96, \mathrm{NNFI}=.95, \mathrm{CFI}=.98, \mathrm{AGFI}=.97, \mathrm{GFI}=.99, \mathrm{RMSEA}=.05$

Table 4: Confirmatory factor analysis result: role conflict

\begin{tabular}{lllllll}
\hline Dimensions & (CFA) & (CFA) & $\boldsymbol{t}$-value & Mean & Std.Dev. & Item-Total Corelation \\
\hline $\begin{array}{l}\text { Role Conflict Scale* } \\
\text { Cronbach Alpha: .62 }\end{array}$ & & & & & & \\
\hline 1 & .49 & .52 & 8.58 & 3.30 & .931 & $.623^{* *}$ \\
\hline 2 & .58 & .68 & 10.66 & 3.00 & .959 & $.691^{* *}$ \\
\hline 3 & .45 & .40 & 6.62 & 3.12 & .947 & $.596^{* *}$ \\
\hline 4 & $.36^{*}$ & & & & & \\
\hline 5 & $.54^{*}$ & & & & & \\
\hline 6 & .63 & .59 & $\mathbf{9 . 5 8}$ & $\mathbf{3 . 0 6}$ & .936 & $.627^{* *}$ \\
\hline
\end{tabular}

Note: Standardized item loadings reported for CFA. $p<.001$ for all loadings. **Correlation is significant at the 0.01 level (2-tailed).

*The question with a factor load below .30 and dropped from the scale ** The question that was dropped for remaining single in the dimension aQuestion giving a correction index and removed from the scale

* Thequestions that correspond to the study of Lewin and Sager (2009). 
As seen in Table 4, a good fit could not be reached as the goodness of fit indicator in the initial version of the role conflict scale (Goodness-of-Fit Statistics: $X 2 / d f=$ $29.09 / 9=3.23, \mathrm{NFI}=.91, \mathrm{NNFI}=.89, \mathrm{CFI}=.93, \mathrm{AGFI}=.94$, $\mathrm{GFI}=.98, \mathrm{RMSEA}=.07)$. The 4th question with a factor load of less than .40 and the 5 th question showing a correction index were dropped from the scale and the scale was subjected to confirmatory factor analysis again and a good fit wasreached(Goodness-of-Fit Statistics: $X 2 / d f=1.36 / 2=0.68, \mathrm{NFI}=.99, \mathrm{NNFI}=1.00, \mathrm{CFI}=1.00$, $A G F I=.99, G F I=1.00, R M S E A=.00)$. Thus, a new 4-item role conflict scale which is valid and reliable (Cronbach's Alpha: .62) in Turkey was obtained.
As seen in Table 5, a good fit could not be reached as the goodness of fit indicator in the initial version of the role ambiguity scale (Goodness-of-Fit Statistics: X2 / $d f=89.50 / 5=17.9, \mathrm{NFI}=.88, \mathrm{NNFI}=.78, \mathrm{CFI}=.89, \mathrm{AGFI}$ $=.75, \mathrm{GFI}=.92, \mathrm{RMSEA}=.21)$. The 4th and 5th questions showing the correction index were dropped from the scale and the scale was subjected to confirmatory factor analysis again and a good fit was obtained (Goodness-of-Fit Statistics: X2/df=1.34/2=.67, NFI=.99, $N N F I=1.00, C F I=1.00, A G F I=1.00, G F I=1.00, R M S E A=.00)$. Thus, a new 3-item role ambiguity scale which is valid and reliable (Cronbach's Alpha: .74) in Turkey was obtained.

Table 5: Confirmatory factor analysis result: role ambiguity

\begin{tabular}{lllllll}
\hline Dimensions & (CFA) & (CFA) & t-value & Mean & Std.Dev. & Item-Total Corelation \\
\hline $\begin{array}{l}\text { Role Ambiguity Scale* } \\
\text { Cronbach Alpha:.735 }\end{array}$ & & & & & & \\
\hline 1 & .52 & .67 & 12.26 & 3.75 & .935 &. $\mathbf{7 8 4 *}$ \\
\hline 2 & .63 & .80 & 14.32 & 3.90 & .874 & $.807^{* *}$ \\
\hline 3 & .71 & .62 & 11.54 & 4.12 & .858 &. $\mathbf{7 1 3 * *}$ \\
\hline 4 & $.81^{*}$ & & & & & \\
\hline 5 & $.72^{*}$ & & & & & \\
\hline
\end{tabular}

Note: Standardized item loadings reported for CFA. $p<.001$ for all loadings. ${ }^{* *}$ Correlation is significant at the 0.01 level (2-tailed).

*The question with a factor load below .30 and dropped from the scale ** The question that was dropped for remaining single in the dimension aQuestion giving a correction index and dropped from the scale

* Thequestions that correspond to the study of Lewin and Sager (2009).

Table 6 : Confirmatory factor analysis result: well-being at work

\begin{tabular}{|c|c|c|c|c|c|c|}
\hline Dimensions & (CFA)* & (CFA) & $t$-value & Mean & Std.Dev. & Item-Total Corelation \\
\hline \multicolumn{7}{|c|}{$\begin{array}{l}\text { Well-Being at Work Scale* } \\
\text { Cronbach Alpha:.75 }\end{array}$} \\
\hline \multicolumn{7}{|c|}{ Negative Effect: .90 } \\
\hline \multicolumn{7}{|c|}{ Anxiety-Comfort: } \\
\hline 1 & $.87^{*}$ & & & & & \\
\hline 2 & $.91^{*}$ & & & & & \\
\hline 3 & $.76^{*}$ & & & & & \\
\hline \multicolumn{7}{|c|}{ Depression-Pleasure::83 } \\
\hline 4 & .75 & .73 & 16.02 & 2.43 & 1.104 & $.816 * *$ \\
\hline 5 & .79 & .78 & 17.82 & 2.30 & 1.149 & $.846 * *$ \\
\hline 6 & .83 & .85 & 20.18 & 2.36 & 1.115 & $.849 * *$ \\
\hline \multicolumn{7}{|c|}{ Angry-Placid: .84 } \\
\hline 7 & .79 & .79 & 18.03 & 2.48 & 1.148 & $.838 * *$ \\
\hline 8 & .79 & .79 & 18.02 & 2.52 & 1.057 & $.842 * *$ \\
\hline 9 & .80 & .80 & 18.27 & 2.52 & 1.130 & $.840 * *$ \\
\hline
\end{tabular}

Bored-Enthusiastic 
Table 6 (Continued): Confirmatory factor analysis result: well-being at work

\begin{tabular}{lcccccc}
\hline Dimensions & (CFA) & (CFA) & t-value & Mean & Std.Dev. & Item-Total Corelation \\
\hline 10 & $.68^{*}$ & & & & \\
\hline 11 & $.66^{*}$ & & & & & \\
\hline 12 & $.71^{*}$ & & & & & \\
\hline Tiredness-Vigour: .86 & & & & & & $.854^{* *}$ \\
\hline 13 & .84 & .83 & 19.35 & 2.92 & 1.163 & $.897^{* *}$ \\
\hline 14 & .89 & .90 & 21.49 & 2.92 & 1.163 & $.833^{* *}$ \\
\hline 15 & .73 & .73 & 16.17 & 2.98 & 1.252 & \\
\hline
\end{tabular}

Pozitive Effect: .91

Anxciety-Comfort

\begin{tabular}{ll}
\hline 16 & $.60^{*}$ \\
\hline 17 & $.80^{*}$ \\
\hline 18 & $.87^{*}$
\end{tabular}

Depression-Pleasure: .86

\begin{tabular}{lllllll}
\hline 19 & .87 & .84 & 19.86 & 3.41 & 1.095 & $.866^{* *}$ \\
\hline 20 & .85 & .87 & 20.76 & 3.44 & 1.062 & $.869^{* *}$ \\
\hline 21 & .74 & .75 & 16.72 & 3.48 & 1.108 & $.825^{* *}$ \\
\hline
\end{tabular}

Angry-Placid

\begin{tabular}{ll}
\hline 22 & $.54^{*}$ \\
\hline 23 & $.74^{*}$ \\
\hline 24 & $.82^{*}$
\end{tabular}

Bored-Enthusiastic: .86

\begin{tabular}{lllllll}
\hline 25 & .80 & .79 & 18.14 & 3.44 & 1.118 & $.848 * *$ \\
\hline 26 & .83 & .84 & 19.94 & 3.59 & 1.140 & $.869 * *$ \\
\hline 27 & .82 & .83 & 19.80 & 3.50 & 1.174 & $.859 * *$
\end{tabular}

Tiredness-Vigour: .81

\begin{tabular}{lllllll}
\hline 28 & .76 & .76 & 16.94 & 3.62 & 1.140 & $.817^{* *}$ \\
\hline 29 & .73 & .72 & 15.92 & 3.30 & 1.170 & $.831^{* *}$ \\
\hline 30 & $\mathbf{. 8 1}$ & $\mathbf{. 8 2}$ & $\mathbf{1 8 . 8 9}$ & $\mathbf{3 . 4 1}$ & $\mathbf{1 . 1 9 0}$ & $\mathbf{. 8 4 0 * *}$ \\
\hline
\end{tabular}

Note: Standardized item loadings reported for CFA. $p<.001$ for all loadings. ${ }^{* *}$ Correlation is significant at the 0.01 level (2-tailed). *The question with a factor load below .30 and dropped from the scale ** The question that was dropped for remaining single in the dimension a the question giving a correction index and dropped from the scale

* The questions corresponding to the study of Daniels (2000).

As seen in Table 6, a good fit could not be reached as the goodness of fit indicator in the initial version of the work well-being scale (Goodness-of-Fit Statistics: $\chi^{2}$ $/ d f=811.29 / 360=2.25, N F I=.89, N N F I=.91, C F I=.93$, $A G F I=.85, G F I=.88, R M S E A=.05)$. The 1st, 2nd, 3rd, 10th, 11th, 12th, 16th, 17th, 18th, 22nd, 23rd, 24th questions showing correction index were dropped from the scale and the scale was re-subjected to confirmatory factor analysis and a good fit was reached (Goodness-of-Fit Statistics: $X 2 / d f=188.48 / 120=1.57, N F I=.95, N N F I=.98$,
$C F I=.98, A G F I=.93, G F I=.95, R M S E A=.03)$. Thus, a new 18-item well-being scale which is valid and reliable (Cronbach Alpha: .83, .84, .86, .86, .86, .81, .75) in Turkey and consisting of 2 sub-dimensions asnegative effect (9 questions) and positive effect ( 9 questions) was obtained (negative effect .90 and positive effect .91).

In the study, the relationships between variables were examined with correlation analysis. The results are shown in Table 7. 
Table 7: Correlation analysis

\begin{tabular}{|c|c|c|c|c|c|c|c|c|c|}
\hline & $\begin{array}{l}\text { Arithmetic } \\
\text { mean }\end{array}$ & $\begin{array}{l}\text { Standard } \\
\text { deviation }\end{array}$ & $\begin{array}{l}\text { Role } \\
\text { Ambiguity }\end{array}$ & $\begin{array}{l}\text { Role } \\
\text { Conflict }\end{array}$ & $\begin{array}{l}\text { Supervisor } \\
\text { Support }\end{array}$ & $\begin{array}{l}\text { Co- } \\
\text { worker } \\
\text { Support }\end{array}$ & $\begin{array}{l}\text { Reported } \\
\text { Job } \\
\text { Competence }\end{array}$ & $\begin{array}{l}\text { Well- } \\
\text { being at } \\
\text { Work } \\
\text { Negative }\end{array}$ & $\begin{array}{l}\text { Well- } \\
\text { being } \\
\text { at Work } \\
\text { Positive }\end{array}$ \\
\hline $\begin{array}{l}\text { Role } \\
\text { Ambiguity }\end{array}$ & 3.94 & .768 & & & & & & & \\
\hline Role Conflict & 3.26 & .703 & .076 & & & & & & \\
\hline $\begin{array}{l}\text { Supervisor } \\
\text { Support }\end{array}$ & 2.62 & .976 & .041 & .111 & & & & & \\
\hline $\begin{array}{l}\text { Co-worker } \\
\text { Support }\end{array}$ & 3.06 & .997 & .079 & .117 & $.578^{* *}$ & & & & \\
\hline $\begin{array}{l}\text { Reported Job } \\
\text { Competence }\end{array}$ & 3.86 & .804 & $-.303^{* *}$ & $-.191^{* *}$ & $.176^{*}$ & $.230^{* *}$ & & & \\
\hline $\begin{array}{l}\text { Well-Being } \\
\text { at Work } \\
\text { Negative }\end{array}$ & 2.60 & .879 & -.007 & -.048 & $-.239 * *$ & $-.187^{* *}$ & -.032 & & \\
\hline $\begin{array}{l}\text { Well-Being at } \\
\text { Work Positive }\end{array}$ & 3.49 & .937 & .011 & .013 & $.255^{* *}$ & $.215^{* *}$ & -.022 & $-.287^{* *}$ & \\
\hline $\begin{array}{l}\text { Emotional } \\
\text { Exhaustion }\end{array}$ & 2.98 & .751 & .077 & .083 & .093 & $-.175^{* *}$ & .076 & .02 & $-.141^{* *}$ \\
\hline
\end{tabular}

** Correlation is significant at the 0.01 level (2-tailed) *Correlation is significant at the 0.05 level (2-tailed)

As seen in Table 7, as a result of the correlation analysis conducted to investigate the relationship between variables, a positive relationship was found between co-worker support and supervisor support $(r$ $=.58)$. Reported job competence showed a negative relationship with role ambiguity $(r=-.30)$, role conflict $(r=-.19)$, and a positive relationship with supervisor support $(r=.18)$, co-worker support $(r=.23)$. Well-being at work (negative effect) showed a negative relationship with supervisor support $(r=-24)$ and co-worker support ( $r=-.19)$. Well-being at work (positive effect) showed a positive relationship withsupervisor support $(r=.26)$ and co-worker support $(r=.22)$, a negative relationship with well-being at work (negative effect) $(r$ $=.29$ ) and emotional exhaustion $(r=.-.14)$. There was no statistically significant relationship between all other variables ( $p>.05)$.

\subsection{Structural Model}

Path analysis was used to determine the relationship between variables. The hypothesis model is shown in Figure 1.

In the first stage, path analysis was performed from role conflict and role ambiguity variables to reported job competence variable. The path from role conflict to reported job competencewas found as (-.16) and the path from role ambiguity to reported job competencewas found as $(-.28)$. Similarly, the path from reported job competence to supervisor supportwas found as (.18) and the path from reported job competence to co-worker supportwas found as (.14). Again, the path from co-worker support to emotional exhaustion was found as (.19). The path from well-being at work (positive effect) to emotional exhaustion was found as (.18), from well-being at work (positive effect) to co-worker support was found as (.12), from well-being at work (positive effect) to supervisor supportwas found as (.17). The path from supervisor support to co-worker support was identified as (.56). While the path from well-being at work (negative effect) to supervisor supportwas $(-.21)$, to co-worker support was found to be invalid ( $t$ $=.-1.56$ ). The path from well-being at work (positive effect) to well-being at work (negative effect)was (-.30). A Good fit was reached in the model (Goodness-of-Fit Statistics: $\mathrm{X} 2 / \mathrm{df}=10.46 / 13=.8, \mathrm{NNFI}=1.00, \mathrm{NFI}=.97$, $\mathrm{CFI}=1.00, \mathrm{AGFI}=.98, \mathrm{GFI}=.99, \mathrm{RMSEA}=.00$ ). However, the invalid path was removed from the model and the model was re-analyzed. 


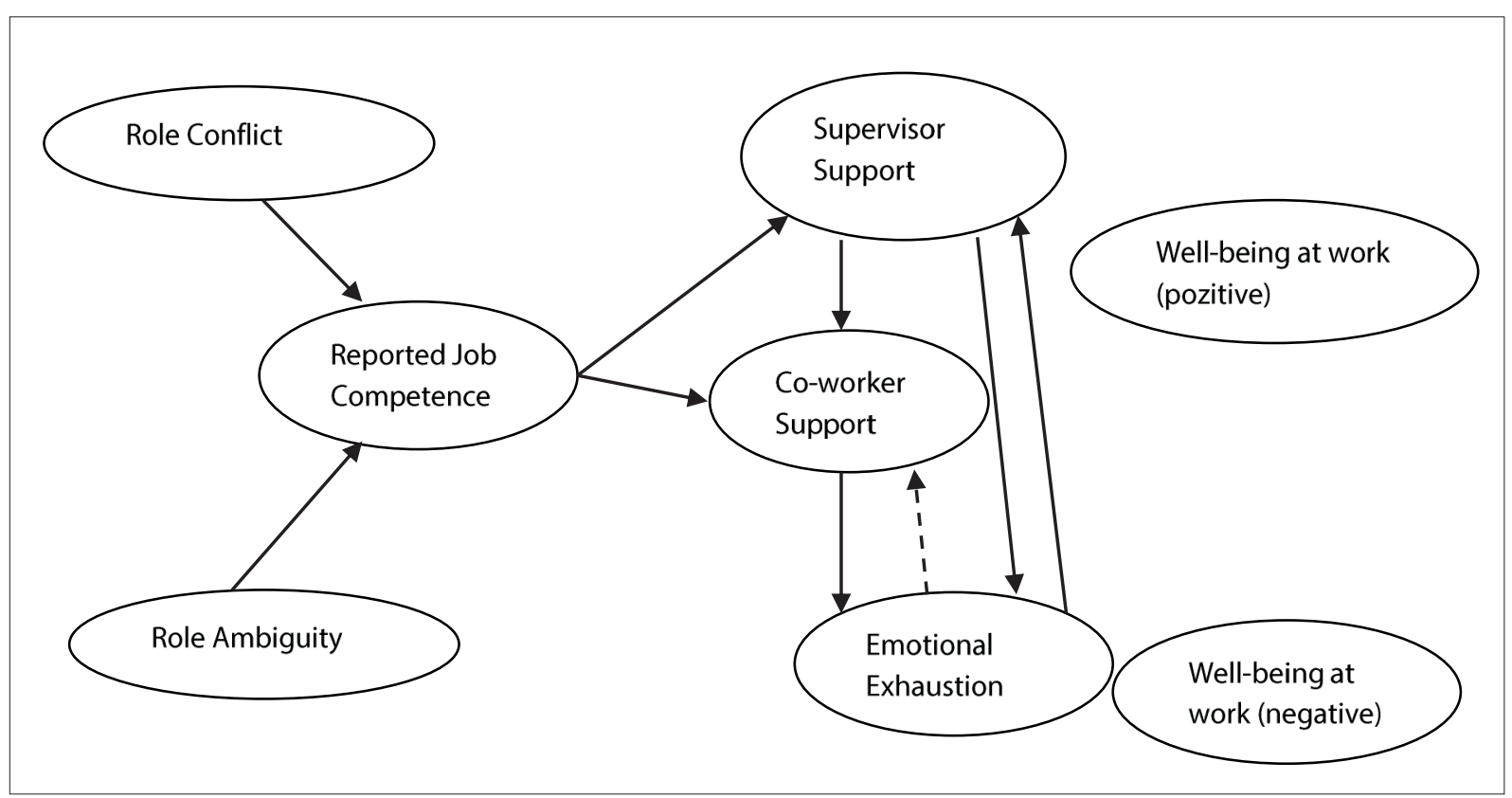

Figure 1: Research result model

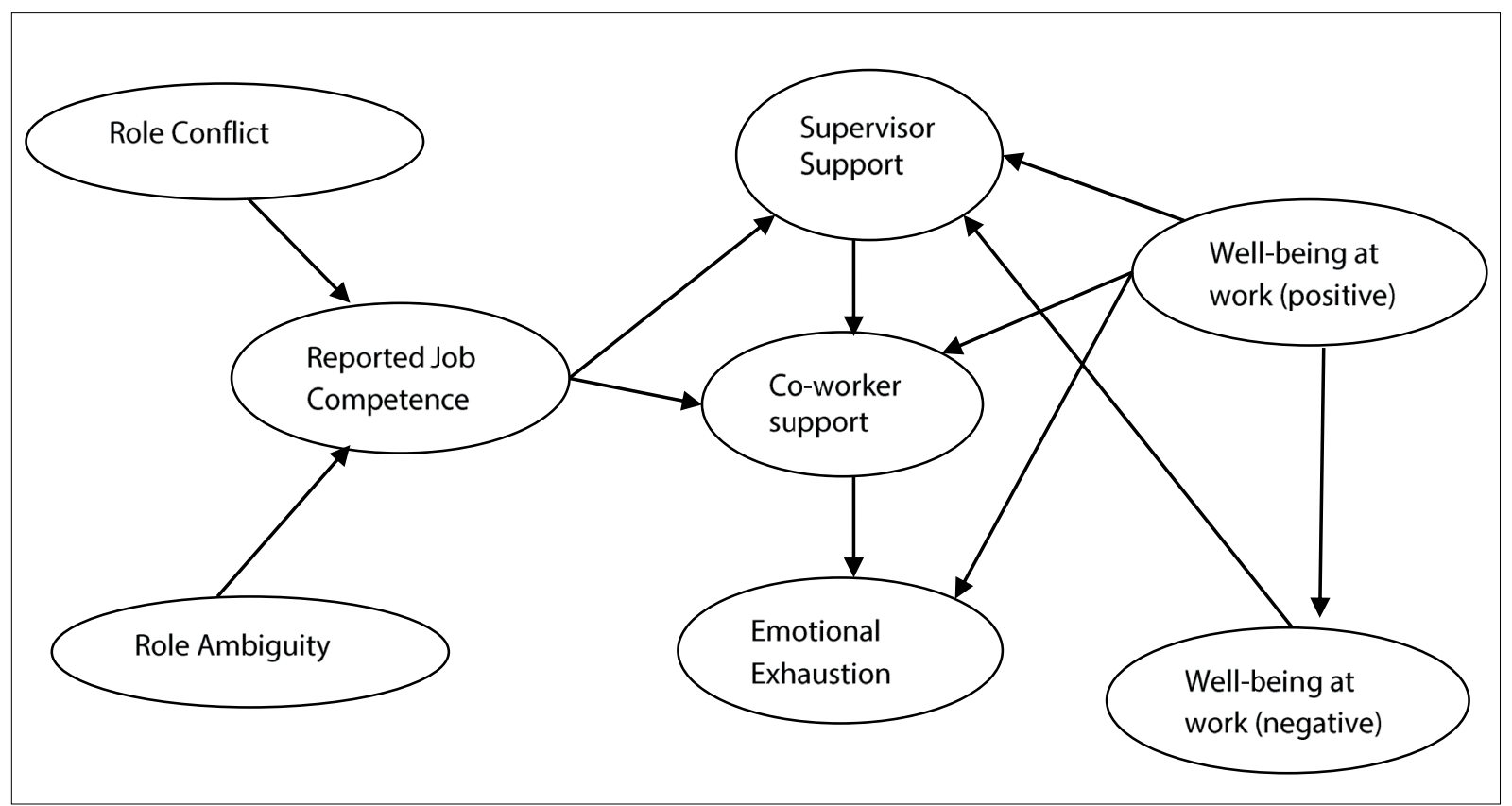

Figure 2: Research result model

In the last stage of the path analysis, path analysis was performed from role conflict and role ambiguity variables to reported job competence variable. The path from role conflict to reported job competencewas(-.16), from role ambiguity to reported job competencewas (-.28). Similarly, the path from reported job competence to supervisor support was found to be (.18), the path from reported job competence to co-worker sup- portwas (.14). Again, the path from co-worker support to emotional exhaustion was identified as (-.19). The path from well-being (positive effect) to emotional exhaustion was (-.18), the path from well-being at work (positive impact) to co-worker support was (.12), the path from well-being at work (positive effect) to supervisor support was found as (.17). The path from supervisor support to co-worker support was identified 
as (.56). The pathfrom well-being at work (negative effect) to supervisor supportwas found as (-.21). The pathfrom well-being at work (positive effect) to being well at work (negative effect)was identified as (-.30). A good fit was reached in the model (Goodness-of-Fit Statistics: $\mathrm{X} 2 / \mathrm{df}=13.10 / 14=.9, \mathrm{NNFI}=1.00, \mathrm{NFI}=.97, \mathrm{CFI}$ $=1.00, \mathrm{AGFI}=.98, \mathrm{GFI}=.99$, RMSEA =. 00). Accordingly, $\mathrm{H} 1 \mathrm{a}, \mathrm{H} 1 \mathrm{~b}, \mathrm{H} 2 \mathrm{a}, \mathrm{H} 2 \mathrm{~b}, \mathrm{H} 2 \mathrm{c}, \mathrm{H} 3, \mathrm{H} 4 \mathrm{a}, \mathrm{H} 4 \mathrm{~b}, \mathrm{H} 4 \mathrm{c}, \mathrm{H} 4 \mathrm{~d}$ were accepted. $\mathrm{H} 4 \mathrm{e}$ wasrejected.

\section{CONCLUSION}

In the study, the relationships between role conflict, role ambiguity, well-being at work, emotional exhaustion, co-worker support, supervisor support and reported job competence variables were investigated. As a result of the study, reported job competence showed a negative significant relationship with role ambiguity, role conflict, and a positive significant relationship with supervisor support and co-worker support. Well-being at work (negative effect) showed a negative significant relationship with supervisor support and co-worker support. Co-worker support showed a positive significant relationship with supervisor support and a negative significantrelationship with emotional exhaustion. Well-being at work (positive effect) showed a positive significantrelationship with supervisor support and co-worker support, and a negative significantrelationship with emotional exhaustion. Well-being at work (negative effect) showed a negative significantrelationship with supervisor support.

In the study, a significant negative relationship was found between reported job competence and role conflict and role ambiguity. When the literature was examined,in the study conducted with the participation of 1133 nurses in two different public hospitals in Ankara, it was seen that nurses with less professional experience have more role ambiguity and role conflict than those with more professional experience (Akbulut, 2013). In a study conducted with 243 healthcare professionals in Istanbul, it was concluded that occupational inadequacy leads to role ambiguity. According to the results of the study conducted with the participation of 251 healthcare professionals in a university hospital in Sakarya, it wasobserved that the role ambiguity and role conflict caused low personal success (Tunç, 2008). In the meta-analysis study, a negative relationship was found between role ambiguity and job performance, while the relationship between role conflict and job performance was found to be negligible (Tubre and Collins, 2000). Role conflict showed a negative relationship with performance, while it did not show a significant relationship with role ambiguity (Amilin, 2017). In a study conducted with 202 employees in Taiwan, a negative relationship was found between role ambiguity and creativity, while a positive relationship was found with role conflict. Self-efficacy and job satisfaction, role conflict and creativity showed the partial mediating effect. Only job satisfaction showed a partial mediating effect between role ambiguiry and creativity (Tang and Chang, 2010). With this study, a significant contribution was made to the literature by reaching the conclusion that role conflict and role ambiguity will decrease as professional competence that is not included in the literature increases.

In the study, a positive significant relationship was found between reported job competence and supervisor support and co-worker support. According to Ilmarinen (1999), reported job competence is a versatile concept based on education, relations with co-workers and supervisor support. All competencies required by the business environment are fed by the support of co-workers and supervisors (IImarinen 2004). When the literature is examined, reported job competence is seen to be affected by education, age, stress, job satisfaction, physical and social functions, relationships in the work environment, and management attitude (Gould et al., 2008; Ilmarinen, 2001; Gharibi et al., 2016). Rhoades and Eisenberger (2002) argue that supervisor and co-worker support leads to positive organizational outcomes such as emotional commitment, high performance and low turnover rate.

In the study, a significant negative relationship was found between co-worker support and emotional exhaustion. When the literature is examined, co-worker support not only increases the level of employee satisfaction from work but also decreases the level of burnout (Leiter \& Maslach, 1988). In addition, it is seen that both a supportive family style and co-worker support are effective in reducing burnout (Torun, 1997). As a result of the study conducted by Buick and Thomas (2001) on mid-level hotel supervisors, it was concluded that supervisors who do not receive support from family, supervisors and co-workers experience more burnout. Similarly, in another study, it was revealed that the social support provided by co-workers and first superiors was in a negative relationship with burnout (Martinussen et al., 2007, p. 240-247).

In the study, well-being at work (positive effect) showed a positive significant relationship with supervisor support and co-worker support, and well-being 
at work (negative effect) showed a positive significant relationship with with supervisor support and co-worker support. In addition, no significant relationship was found between well-being at work (negative effect) and co-worker support. According to a study conducted in the health sector, it was seen that supervisor support affects employees' well-being at work (McKee et al., 2011).

The results of this study contribute to the literature by proving the relationships of labor relations concepts. In this study, it is concluded that healthcare workers who feel professional competence experience less role conflict and role ambiguity. In other words, this result is an important finding which reveals that the professional competence of healthcare workers should be given importance in recruitment and continuation of the job. The fact that this result is related to the result that the healthcare worker, who feels the support of his/her co-worker and manager in the workplace, feels more professionally competent, reveals an important finding. In health institutions where teamwork is intense (Salas, Sims and Burke, 2005; Thomas, 2011; Morguelan, 2013; Salas and Rosen, 2013), it is a significant finding that reveals co-worker compliance and management compliance. Similarly, the fact that healthcare workers who feel good at work receive more co-worker and executive support also indicates this relationship. Finally, the fact that healthcare workers who feel good at work experience less emotional exhaustion make a significant contribution to the literature. Because healthcare workers are employees who are heavily exposed to emotional exhaustion (Maslach, 1982; Delvaux, Razavi, and Farvacques, 1988; Schaufeli and Enzmann, 1988). This study makes a significant contribution to the literature in terms of showing the connection of emotional exhaustion with co-worker and executive support through a multivariate research design. 


\section{References}

Akbulut AB. (2013). Ankara Üniversitesi hastaneleri hemşirelerinde işe bağlı gerginlik düzeyi ve rol çatışması- rol belirsizliği durumu ve diğer etmenler. Yüksek Lisans Tezi. Türkiye Cumhuriyeti Ankara ÜniversitesiSağlık Bilimleri Enstitüsü,Ankara.

Altındiş, S. ve Ergin, A. (2008). Araştırma Evreni ve Örneklem. Konya: Eğitim yayınevi. pp.81-104.

Amilin, A. (2017). The impact of role conflict and role ambiguity on accountants' performance : the moderating effect of emotional quotient. European Research Studies Journal, 20(2A), 237-249.

Babin, B.J.,Boles J.S. (1996). The Effects of Perceived CoWorker Involvement and Supervisor Support on Service Provider Role Stress, Performance and Job Satisfaction. Journal of Retailing, 72 (1), 57-75.

Bakker, A. B.,\& Oerlemans, W. (2011). Subjective well-being in organizations. The Oxford handbook of positive organizational scholarship, 49, 178-189.

Barutçu, E. ve Erinkan, C. (2008). Günümüzün önemli sorunlarından biri olarak tükenmişlik sendromu ve Denizli'de yapılan bir araştırma. Ege Academic Review, 8(2), 541-561.

Bhanthumnavın,D. (2003). Perceived Social Support From Supervisor and GroupMembers Psychological and Situational Characteristics as Predictors of Subordinate Performance in Thai Work Units. Human Resource Development Quarterly, 14(1), 74-97

Bradburn, N.M. (1969). The structure of psychological well-being. Chicago: Aldine Publishing Company.

Buchbinder, S.B. and Buchbinder, D. (2012). Managing Healthcare Professionals. United Stated of America: Jones \&Bartlett Learning, 211-247.

Buick,I.,Thomas, M. (2001). Why do middle managers in hotels burn out?.International Journal of Contemporary Hospitality Management, 13(6), 304-309.

Cordes, C. L., T. W. (1993). A review and an integration of research on job burnout. The Academy of Management Review, 18(4), 621-656.

Chiu, M.C., Wang, M.J.J., Lu, C.W., Pan, S.M., Kumashiro, M., Imarinen, J. (2007). Evaluating work ability and quality of life for clinical nurses in Taiwan. Nursing Outlook, 55, 318-326.

Christopher, J.C. (1999). Situating psychological well-being: exploring the cultural roots of its theory and research.Journal of Counseling and Deveelopment, 77, 141-152.

Çam, O. (1992). Tükenmişlik envanterinin geçerlik ve güvenirliğinin araştırılması. VII. Ulusal Psikoloji Kongresi. 22th September 1992 Ankara (Turkey).

Daniels, K.(2000). Measures of five aspects of affective well-being at work.Human Relations, 53(2), 275-294.

Deconinck J.B.,Johnson J.T. (2009). The effects of perceived supervisor support, perceived organizational support, and organizational justice on turnover among salespeople.Journal of Personal Selling \& Sales Management, 29 (4), 333-350.
Delvaux, N., Razavi, D. and Farvacques, C. (1988). Cancer care: a stress for health professionals. Social Science and Medicine, 27, 159-66.

Eisenberger, R., Stinglhamber, F., Vandenberghe, C., Sucharski I.L., Rhoades, L. (2002). Perceived supervisor support: contributions to perceived organizational support and employee retention. Journal of Applied Psychology, 87(3), 565-573.

Ergin, C. (1992). Doktor ve hemşirelerde tükenmişlik ve Maslach tükenmişlik ölçeğinin uyarlanması. VII. Ulusal Psikoloji Kongresi, 22th September 1992 Ankara (Turkey).

Esatoğlu, A.E., Ağırbaş, I., Akbulut, Y., Çelik, Y. (2004). Hastanelerde rol çatışması ve rol belirsizliği: Sağlık Bakanlığı hastanelerinde bir uygulama.Amme ldaresi Dergisi, (4), 133-146.

Freudenberger, H.J. (1974). Staff burn-out.Journal of Social Issues,30(1), 159-165.

Friesen, D.,Sarros, J.C. (1989). Sources of burnout among educators.Journal of Organizational Behavior, 10(2), 179-188.

Harris, J.I., Winskowski,A.M., Engdahl, B.E. (2007). Types of workplace social support in the prediction of job satisfaction. The Career Development Quarterly, 56, 151-156.

Gharibi, V., Mokarami, H., Taban, A., Aval, M.Y., Samimi, K., Salesi, M. (2016). Effects of work-related stress on work ability index among Iranian workers. Safety and Health at Work, 7,43-48.

Gould, R., Ilmarinen, J., Järvisalo, J., Koskinen, S. (2008). Dimensions of work ability: results of the Health 2000 Survey.

Ilmarinen, J. (2001). Ageing workers in Finland and in the European Union: Their situation and the promotion of their working ability, employability and employment. Geneva Papers on Risk and Insurance-Issues and Practice, 26, 623641.

Ilmarinen, J. (2004). Preface. In Past, Present and Future of Work Ability. J. Ilmarinen \& S. Lehtinen (eds.), In People and Work - Research Reports 65, National Institute of Occupational Health, Helsinki, pp. III- IV.

Ilmarinen, J.,Rantanen, J. (1999). Promotion of work ability during ageing. American Journal of Industrial Medicine, 1, 21-23.

Işık, E. (2014). Rol belirsizliği, rol çatışması, kurumsal destek ve sağlık çalışanlarında tükenmişlik.Yüksek Lisans Tezi. T.C. Beykent Üniversitesi Sosyal Bilimler Enstitüsü, İstanbul.

Jackson S.E., Schwab R.L., Schuler, R.S. (1986). Toward an understanding of the burnout phenemenon. Journal of Applied Psychology,71(4), 630-640.

Kale, E.(2015). Lider desteği ve iş arkadaşları desteğinin iş performansı üzerine etkileri: iş tatmini ve yaşam tatmininin aracı rolü. International Journal of Economic \& Administrative Studies, 7(14), 103-120.

Kane, T.M. (1992). The assessment of professional competence. Evaluation \& The Health Professions, 15(2), 163-182. 
Kahn, R. L., Wolfe, D. M., Quinn, R. P., Snoek, J. D. and Rosenthal, R. A. (1964). Organizational stress: studies in role conflict and ambiguity, Newyork:Wiley.

Karasar, N. (2004). Bilimsel araştırma yöntemi. Ankara: Nobel Yayınevi.

Katz, D., Kahn, R.L. (1978). The social psychology of organizations. Toronto: John Wiley \& Sons.

Katz, D., Kahn, R.L.(1977). Örgütlerin Toplumsal Psikolojisi. Ankara: Doğan Basımevi.

Kim, H.J., Shin, K.H., Umberit, W.T. (2007). Hotel job burnout: the role of personality characteristics.Hospitality Management, 26, 421-434.

Koeck, C. (1998). Time for organizational development in healthcare organisations: Improving quality for patients means changing the organisation. British Medical Journal, 317(7168), 1267-1268.

Leiter, M.P.,Maslach,C. (1988). The impact of interpersonal environment on burnout and organizational commitment. Journal of Organizational Behavior,9, 297-308.

Lewin, E.J.,Sager,J.K. (2009). An investigation of the influence of coping resources in salespersons' emotional exhaustion. Industrial Marketing Management, 38, 798-805.

Litchfield, E.R., Oakland, J.M., Anderson, J. (2002). Promoting and evaluating competence in on-line dietetics education. Journal of the American Dietetic Association, 102(10), 14551458.

Madera, J.M., Dawson, M., Neal, J.A.(2013). Hotel managers' perceived diversity climate and job satisfaction: the mediating effects of role ambiguity and conflict.International Journal of Hospitality Management, 35, 28-34.

Martinussen, M., Richardsen, A.M., Burke, R.J. (2007). Job demands, job resources, and burnout among police officers. Journal of Criminal Justice, 35, 239- 249.

Maslach C. (1982). Burnout: The cost of caring. New Jersey, Prentice Hall: 32-9.

Maslach, C.,\& Leiter, M. P. (1999). Take this job and love it!: Six ways to beat burnout. Psychology Today-New York-, 32, 5053.

Maslach, C.\& Leiter, M.P. (1997). The Truth about Burnout,San Francisco: Jossey-Bass.

Maslach, C., Schaufeli, W. B., \& Leiter, M. P. (2001). Job burnout. Annual review of psychology, 52(1), 397-422.

McKee, M.C., Driscoll, C., Kelloway, E.K., Kelley, E. (2011). Exploring linkages among transformational leadership, workplace spirituality and wellbeing in health care workers. Journal of Management, Spirituality \& Religion, 8(3), 233-255.

Meydan, C.H., Basım, H.N ve Çetin, F. (2011). Örgütsel adalet algısı ve örgütsel bağlılığın tükenmişlik üzerine etkisi: Türk kamu sektöründe bir araştırma, Bilig, (57), 175-200.

Minnick, W. D. (2012). Organizational and personal characteristics that influence role conflict and role ambiguity in the safety professional (Doctoral dissertation).
Morguelan, B. (2013). Recognizing the elixir of excellent patient care: Nurse-physician relationships. Beginnings (American Holistic Nurses'Association), 33(2), 10-12.

Mossholder, K.W., Settoon, R.P., Henegan S.C. (2005). A relational perspective on turnover: examining structural, attitudinal and behavioral predictors.Academy of Management Journal, 48(4), 607-618.

Montello, Daniel R. and Sutton, Paul C. (2006). An introduction to scientific research methods in geography. United States of America: SAGE Publications.

Patton, M.Q. (2014). Michael Quinn: Nitel Araştırma ve Değerlendirme Yöntemleri. (Çev.: Mesut Bütün ve Selçuk Beşir Demir), Ankara: Pegem Akademi.

Paulin, M., Ferguson, R.J., Bergeron, J. (2006). Service climate and organizational commitment: The importance of customer linkages.Journal of Business Research,59, 906-915.

Palomino, M. N., Frezatti, F. (2016). Role conflict, role ambiguity and job satisfaction: Perceptions of the Brazilian controllers. Revista de Administração (São Paulo), 51(2), 165-181.

Pearce, J. L. (1981). Bringing some clarity to role ambiguity research, The Academy of Management Review, 6(4), 665-674.

Peterson, M.F., Smith, P.B., Akande, A., Ayestaran, S., Bochner, S., Callan, V., Hofmann, K. (1995). Role conflict, ambiguity, and overload: A 21-nation study. Academy of Management Journal, 38(2), 429-452.

Rhoades, L.,Eisenberger, R. (2002). Perceived organizational support: A review of the literature. Journal of Applied Psychology, 87, 698-714.

Riggio, R. E. (2014). Endüstri ve örgüt psikolojisine giriş. Nobel Akademik Yayıncılık.

Rizzo, J.R., House, R.J., Lirtzman, S.I. (1970). Role conflict and ambiguity in complex organizations. Administrative Science Quarterly, 15(2), 150-163.

Ryff, C.D. (1989). Happiness is everything, or is it? explorations on the meaning of psychological well-being.Journal of Personality and Social Psychology, 57(6), 1069-1081.

Salas, E. and Rosen, M. A. (2013). Building high reliability teams: Progress and some reflections on teamwork training. BMJ Quality \& Safety, 22(5), 369-37.

Salas, E., Sims, D.E. and Burke, C. S. (2005). Is there a "big five" in teamwork?. Small Group Researchers, 36, 555-599.

Schaufeli, W. B. (2011). Work engagement: A key concept of a positive occupational health psychology. In Presentation from: 2011 Wellness in the workplace conference, Bloemfontein.

Schaufeli W.B. and Enzmann D. (1998). The burnout companion to study and practice: a critical analysis. Washington: Taylor \&Francis.

Singh, J., Goolsby, J.R., Rhoads, G.K. (1994). Behavioral and psychological consequences of boundary spanning burnout for customer service representatives. Journal of Marketing Research, 31(4), 558-569. 
Skaalvık, E.M. and Skaalvık, S. (2009). Does school context matter? relations with teacher burnout and job satisfaction. Teaching and Teacher Education. 25, 518-524.

Steiger, J.H. (1994). Factor analysis in the 1980's and the 1990's: some old debates and some new developments. Trends and Perspectives in Empirical Social Research, 201-224.

Sparks, K., Faragher, B., Cooper, C.L. (2001). Well-being and occupational health in the 21 st century workplace. Journal of Occupational and Organizational Psychology, 74 (4), 489-509.

Srikanth, P.B.Jomon, M.G. (2013). Role ambiguity and role performance effectiveness: moderating the effect of feedback seeking behaviour.Asian Academy of Management Journal, 18(2),105-127.

Stevens, J.P. and Pituch, K.A. (2009). Applied Multivariate Statistics for The Social Sciences. London and New York: Taylor\&Francis Group.

Sumeli, F. (2011). Özel Bir Hastane Çalışanlarının Tükenmişlik ve iş Doyumu Düzeylerinin Bazı Değişkenler Açısından İncelenmesi.Marmara Üniversitesi/Sağlık Bilimleri Enstitüsü, İstanbul.

Sürgevil, O. (2006). Çalışma hayatında tükenmişlik sendromu tükenmişlikle mücadele teknikleri.Ankara: Nobel YayınDağıtım.

Sweeney, J. T. and Summers, S. L. (2002). The effect of the busy season workload on public accountants' job burnout. Behavioral Research In Accounting, 14, 223-245.

Tang, Y.T. and Chang, C.H. (2010). Impact of role ambiguity and role conflict on employee creativity", African Journal of Business Management, 4(6), 869-881.

Thomas, E. J. (2011). Improving teamwork in healthcare: Current approaches and the path forward. BMJ Quality \& Safety, 20(8), 647-650.

Thompson, J. M., Buchbinder, S. B., and Shanks, N. H. (2012). An overview of healthcare management. United Stated of America: Jones\&Bartlett Learning, 1-15.
Tehrani, N., Humpage, S., Willmott, B., \& Haslam, I. (2007). What's happening with well-being at work. Change Agenda. London:Chartered Institute of Personnel Development.

Topliceanu, L, Bibire, L,and Nistor, D. (2015). Professional competences of the personnel working on quality control and food safety in the food industry. Procedia-Social and Behavioral Sciences, 180, 1030-1037.

Torun, A. (1997). Stres ve Tükenmişlik, Endüstri ve Örgüt Psikolojisi-2. Baskı, Editör: Suna Tevrüz, Türk Psikologlar Derneği ve Kalder Derneği Ortak Yayını, İstanbul.

Trayambak, S, Kumar, P, Jha, A.N. (2012). A conceptual study on role stressors, their impact and strategies to manage role stressors.IOSR Journal Of Business And Management, 4(1), 44-48.

Tubre, T.C. and Collins, J.M. (2000). Jackson and Schuler (1985) revisited: A Meta-analysis of the relationships between role ambiguity, role conflict, and job performance, Journal of Management, 26 (1), 155-169.

Warr, P. (1990). The measurement of well-being and other aspects of mental health.Journal of Occupational Psychology,63, 193-210.

Warr, P. (2011). Work, happiness, and unhappiness. Psychology Press.

What Works Centre for Wellbeing. (2017). Good work, wellbeing and performance. Erişim adresihttps://www. whatworkswellbeing.org/product/good-work-wellbeing-and-changes-inperformance-outcomes/

Yoon, J., Lim, J.C. (1999). Organizational support in the workplace: The case of Korean hospital employees. Human Relations, 52, 923-945.

Yörükoğlu, S. (2008). Özel bir hastanede çalışan sağlık personelinin rol çatışması, rol belirsizliği ve tükenmişlik düzeylerinin belirlenmesi. Yüksek Lisans Tezi, Haliç Üniversitesi/ Sağlık Bilimleri Enstütüsü, İstanbul. 